\title{
Endogeniczny potencjał kreacji prośrodowiskowych funkcji obszarów wiejskich - próba oceny w oparciu o bazę Wskaźników Zrównoważonego Rozwoju GUS
}

\section{Endogenous potential for creating pro-environmental functions of rural areas - an evaluation attempt based on the CSO's Sustainable Development Indicators database}

\author{
Katarzyna BAŃKOWSKA \\ Instytut Rozwoju Wsi i Rolnictwa PAN \\ Zakład Modelowania Ekonomicznego \\ Nowy Świat 72, 00-330 Warszawa \\ kbankowska@irwirpan.waw.pl
}

\begin{abstract}
Zarys treści: Zrównoważony rozwój rolnictwa jest przedmiotem wielu analiz. Jednakże większość dotychczasowych badań na gruncie polskim koncentruje się głównie na ekonomicznych aspektach wielofunkcyjności obszarów wiejskich, takich jak nowe miejsca pracy, przedsiębiorczość ludności wiejskiej, inicjatywy inwestycyjne. Brakuje prac służących ocenie pozafinansowych czynników wpływających na kreację nowych, korzystnych dla środowiska naturalnego funkcji obszarów wiejskich. Znaczenie ma zatem rozpoznanie tych czynników, które na poziomie lokalnym przyczyniają się do wykształcenia trwałych (niezależnych od wsparcia zewnętrznego) funkcji prośrodowiskowych. W niniejszym opracowaniu podjęto próbę takiej oceny na podstawie danych statystyki masowej publikowanych przez GUS. Analizie poddano krajowe wskaźniki zrównoważonego rozwoju z okresu 2004-2014 na poziomie powiatów, w tym wskaźniki ładu środowiskowego oraz wybrane metodą ekspercką wskaźniki ładów: społecznego, gospodarczego i instytucjonalno-politycznego. Kartogramy przedstawiające przestrzenne zróżnicowanie potencjału powiatów w kreacji funkcji prośrodowiskowych wykonano w oparciu o narzędzie wizualizacji dostępne w aplikacji GUS Wskaźniki Zrównoważonego Rozwoju - moduł lokalny (http:// wskaznikizrp.stat.gov.pl).
\end{abstract}

Słowa kluczowe: funkcje obszarów wiejskich, działania prośrodowiskowe, zrównoważony rozwój.

\section{Wprowadzenie}

Przemiany priorytetów światowej polityki wskazują na coraz większą wagę ochrony środowiska i stanowią jeden z bodźców kreacji prośrodowiskowych funkcji obszarów wiejskich. Założenia zrównoważonego rozwoju (sustainable development) nakazują konieczność równoległej realizacji celów ekologicznych, społecznych i kulturowych (Paszkowski 2001; Woś i Zegar 2002; Zegar 2012) oraz wymóg trwałości otrzymywanych efektów. Przyrod- 
nicze funkcje rolnictwa bywają utożsamiane w literaturze z pochodną realizacji funkcji produkcyjnych. Jednak obszary wiejskie z racji swej specyfiki mogą odgrywać szczególną rolę $w$ realizacji działań prośrodowiskowych w znacznie szerszym rozumieniu niż tylko funkcje rolnictwa, co potwierdza (zaistniała w dyskusjach ekonomistów rolnych na przełomie XX i XXI w.) koncepcja zrównoważonego rozwoju i powiązanej z nim wielofunkcyjności obszarów wiejskich. Obok produkcyjnych funkcji sektora rolnego wyróżnia się również funkcje środowiskowo-przestrzenne i usługowe (Adamowicz 2004). W innym ujęciu sektor rolny pełni funkcje rynkowe i pozarynkowe dzielące się na: produkcyjne, społeczne, kulturowe i przyrodnicze (Wilkin 2010). Znany jest również system klasyfikacji funkcji rolnictwa na cztery grupy (Huylenbroeck i in. 2007; ryc. 1): funkcje zielone (zarządzanie zasobami ziemi, utrzymanie bioróżnorodności, stwarzanie warunków dla dziko żyjącej fauny i flory), funkcje niebieskie (gospodarka wodna i energetyczna), funkcje żółte (spójność i żywotność obszaru wiejskiego) oraz funkcje białe (bezpieczeństwo żywnościowe i bezpieczeństwo żywności). Na potrzeby niniejszego opracowania przyjęto, iż analizie zostanie poddany lokalny potencjał kreowania wszelkich działań korzystnych dla środowiska naturalnego - pojęcie funkcji prośrodowiskowych będzie zatem najbliższe funkcjom „zielonym i niebieskim”.

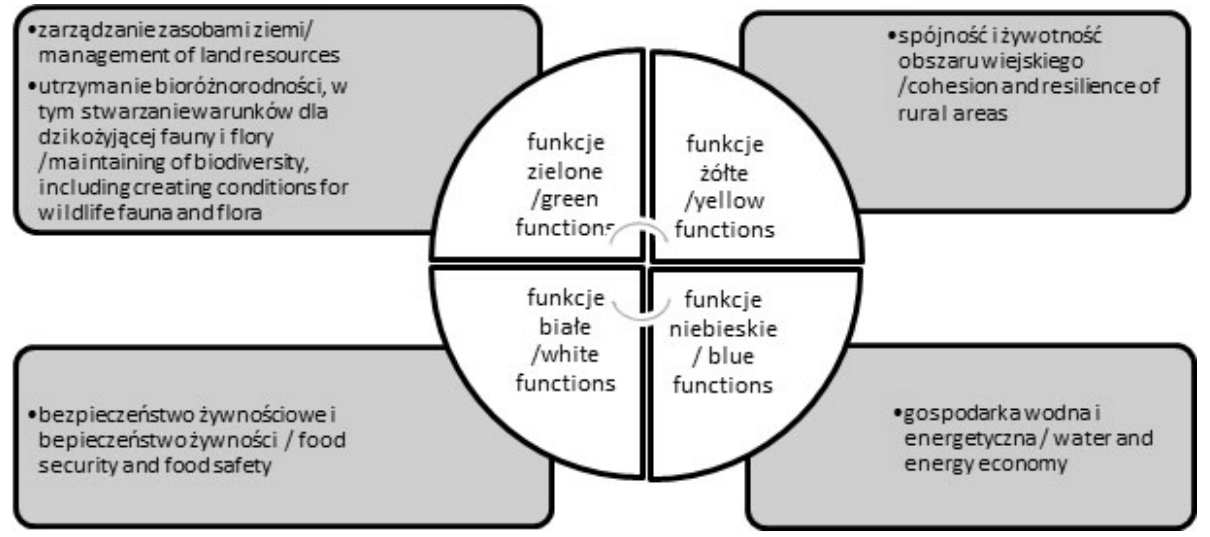

Ryc. 1. System klasyfikacji funkcji rolnictwa

Źródło: opracowanie własne za Huylenbroeck i in. (2007).

Classification of the functions of agriculture

Source: own elaboration based on Huylenbroeck et al. (2007).

Aktualna polityka Unii Europejskiej propaguje pośród Europejczyków zmianę nawyków w kierunku wykształcenia postaw prośrodowiskowych. Szerzenie tej idei opiera się m.in. na licznych obwarowaniach prawnych, od których zależne jest uzyskiwanie wsparcia finansowego z funduszy UE w wielu dziedzinach gospodarki. Takie podejście powoduje pośrednie oddziaływanie na ogół społeczeństwa, jednakże ingeruje w wolny rynek i nie zawsze w jednakowy sposób oddziałuje na wszystkich potencjalnych jego uczestników. Wspólna Polityka Rolna stwarza szanse uzyskania renty politycznej, co powoduje, że dochody rolników nie są skutkiem działania rynku, a instrumentów wsparcia, z których nie mogą skorzystać pozostali mieszkańcy obszarów wiejskich, również odpowiadający za stan środowiska przyrodniczego. Mechanizm renty politycznej dotyczącej środowiskowych funkcji obszarów wiejskich dotyczy m.in.: 
- zachowania różnorodności biologicznej,

- dostarczania alternatywnych źródeł energii,

- propagowania ekologicznych metod produkcji żywności,

- utrzymywania użytków proekologicznych i kontynuacja gospodarki na terenach o niekorzystnych warunkach gospodarowania.

Literatura przedmiotu wskazuje na uzależnienie dostępu do określonego rodzaju wsparcia od warunków naturalnych, nie odpowiada jednak na pytanie o inne (niż zewnętrzne) bodźce wyboru działalności przyjaznej środowisku (Brodzińska 2009; Fałkowski 2010; Miś 2013; Nowak i Wójcik 2013; Niedzielski 2015). Skupienie większości analiz na istniejących instrumentach wsparcia finansowego oraz związanych z nimi restrykcji prawnych znacznie ogranicza możliwość poznania całego procesu powstawania nowych funkcji obszarów wiejskich, gdyż sprowadza się tylko do rozpoznania wpływu wybranych czynników zewnętrznych, narzuconych odgórnie na proces. Istnieją m.in. opracowania dotyczące sytuacji dochodowej gospodarstw rolnych, w których programy środowiskowe są wymieniane jako narzędzie wyrównujące ekonomiczne szanse gospodarstw ekstensywnych (Czyżewski i Smędzik-Ambroży 2013) czy porównujące opłacalność skorzystania z programów rolnośrodowiskowych z intensyfikacją produkcji (Klepacka-Kołodziejska 2008). Dotychczas w literaturze przedmiotu brakuje wiedzy dotyczącej oddolnych czynników mogących również wpływać na kreację funkcji prośrodowiskowych. Na potrzeby niniejszego opracowania założono jednakże, że poza prawnymi i finansowymi czynnikami na podejmowanie działań na rzecz środowiska oddziałują także uwarunkowania lokalne, takie jak postawy i poziom świadomości mieszańców, obecność cennych zasobów przyrodniczych czy występowanie potencjalnych źródeł emisji zanieczyszczeń.

„Zrównoważony rozwój jest podstawowym celem polityki rozwoju prowadzonej na szczeblu krajowym, regionalnym i lokalnym w oparciu o odpowiednie dokumenty strategiczne" (GUS 2015, s. 48), a jego monitorowaniu służy lista wyodrębnionych wskaźników ładu gospodarczego, społecznego, środowiskowego i instytucjonalno-politycznego. Baza Wskaźników Zrównoważonego Rozwoju GUS umożliwia analizę danych w trzech modułach: krajowym, regionalnym - na poziomie regionów i województw oraz lokalnym - na poziomie powiatów. Badanie wskaźników ładu środowiskowego oraz wybranych wskaźników pozostałych ładów (pomimo braku wydzielenia odrębnych danych dla wsi) może stanowić jeden z punktów wyjścia do zobrazowania oddolnego potencjału kreacji funkcji prośrodowiskowych badanych obszarów.

Agregacja przestrzenna na poziomie powiatu może budzić pytania o to, czy dane te odwzorowują wartości wskaźników obszarów wiejskich. Przystępując do niniejszej analizy, wyłączono miasta na prawach powiatu, przyjmując założenie, że wartości średnie wskaźników (w dużym uproszczeniu) w pozostałych powiatach odwzorowują pośrednio sytuację obszarów wiejskich. Przesłanką do przyjęcia tego założenia było 90\% udziału obszarów wiejskich w powierzchni ogólnej kraju. Należy jednak mieć na uwadze margines błędu wynikający z faktu, że większość wskaźników cząstkowych analizowanych ładów nie odnosi się do powierzchni i na ich wartość wpływać mogą także zjawiska generowane w ośrodkach miejskich należących do danej jednostki administracyjnej. Pogłębioną analizę porównawczą przy wykorzystaniu narzędzia wizualizacyjnego aplikacji GUS Wskaźniki Zrównoważonego Rozwoju - moduł lokalny utrudnia również różnica mian dostępnych wskaźników. 
Dobierając dane mogące obrazować lokalny potencjał kreacji prośrodowiskowych funkcji obszarów wiejskich, listę wskaźników ładu środowiskowego poszerzono o pięć wskaźników ładu społecznego (odnoszących się do edukacji i wzorców konsumpcji), jeden wskaźnik ładu gospodarczego (dotyczący ścieżek rowerowych), a także pięć wskaźników ładu instytucjonalno-politycznego. Mankamentem narzędzia wizualizacji dostępnego w aplikacji GUS okazała się niemożliwość samodzielnego ustawienia przez użytkownika prezentowanych na kartogramach przedziałów. Wygenerowane kartogramy umożliwiają zatem jedynie poglądowe rozeznanie różnic natężenia wartości (ciemniejszy kolor oznacza wyższą wartość) danego wskaźnika w powiatach. Ograniczenie doboru skali przedziałów zmniejsza porównywalność otrzymanych wykresów pomiędzy badanymi latami (a zarazem zmniejsza znaczenie legend kartogramów).

\section{Charakterystyka wybranych wskaźników ładu środowiskowego}

Pośród wskaźników ładu środowiskowego dostępnych w bazie GUS na poziomie lokalnym znalazły się dane dotyczące sześciu dziedzin, tj. bioróżnorodności i użytkowania gruntów, zmian klimatu, energii, ochrony powietrza oraz gospodarki odpadami. Listę analizowanych wskaźników wraz z ich średnimi krajowymi wartościami w latach 2004-2014 prezentuje tabela 1.

O predestynacji danego obszaru do pełnienia określonych funkcji decydują uwarunkowania naturalne. W przypadku funkcji prośrodowiskowych wskaźnikiem naturalnych uwarunkowań może być udział zalesień bądź obszarów objętych prawną ochroną w powierzchni danego terytorium. Wartości obu tych wskaźników na przestrzeni badanych lat ulegały niewielkim zmianom w odniesieniu do całego kraju. Największym udziałem powierzchni chronionej charakteryzowały się powiaty zlokalizowane w regionach górskich,

Tabela 1. Dynamika wartości wskaźników ładu środowiskowego dla Polski w latach 2004-2014

\begin{tabular}{|c|c|c|c|c|}
\hline \multicolumn{2}{|c|}{ Wyszczególnienie } & 2004 & 2005 & 2006 \\
\hline \multicolumn{2}{|l|}{ Lesistość (\%) * } & 28,7 & 28,8 & 28,9 \\
\hline \multicolumn{2}{|c|}{$\begin{array}{l}\text { Udział obszarów prawnie chronionych w powierzchni } \\
\text { ogółem (\%) }\end{array}$} & 32,52 & 32,54 & 32,12 \\
\hline \multicolumn{2}{|c|}{$\begin{array}{l}\text { Wydatki gmin na ochronę powietrza atmosferycznego } \\
\text { i klimatu w zł na } 1 \text { mieszkańca }\end{array}$} & - & - & - \\
\hline \multirow{3}{*}{$\begin{array}{l}\text { Zużycie energii elektrycznej } \\
\text { w kWh na } 1 \text { mieszkańca }\end{array}$} & ogółem & 597,3 & 696,1 & 723,2 \\
\hline & w mieście & 703,4 & 718,0 & 746,1 \\
\hline & na wsi & 431,9 & 666,2 & 691,8 \\
\hline \multirow{2}{*}{$\begin{array}{l}\text { Emisja zanieczyszczeń powie- } \\
\text { trza z zakładów szczególnie } \\
\text { uciążliwych (kt/rok) }\end{array}$} & gazowych & 213613,8 & 213706,2 & $223353,9^{m}$ \\
\hline & pyłowych & 123,0 & 110,0 & $102,5^{m}$ \\
\hline \multirow{2}{*}{$\begin{array}{l}\text { Dzikie wysypiska* odpadów } \\
\text { na } 100 \mathrm{~km}^{2}\end{array}$} & liczba (szt.) & - & - & - \\
\hline & powierzchnia $\left(\mathrm{m}^{2}\right)$ & - & - & - \\
\hline
\end{tabular}

*na poziomie powiatów zamiast wskaźnika lesistości porównano wskaźnik intensywności zalesień, zaś zamiast wskaźnika dzikich wysypisk odpadów wskaźnik zebranych odpadów komunalnych na1 mieszkańca; $m$ - zmiana metodyki GUS; - brak danych.

Źródło: GUS http://wskaznikizrp.stat.gov.pl (wygenerowano 5-8.04.2016) 
a także w pasie pojezierzy. Powiaty z dużym udziałem powierzchni prawnie chronionej często charakteryzował także wysoki stopień lesistości. Oba te wskaźniki opisują różne cechy badanych obszarów, o czym świadczyć może wskaźnik korelacji tych zmiennych, wynoszący w badanych latach 0,41.
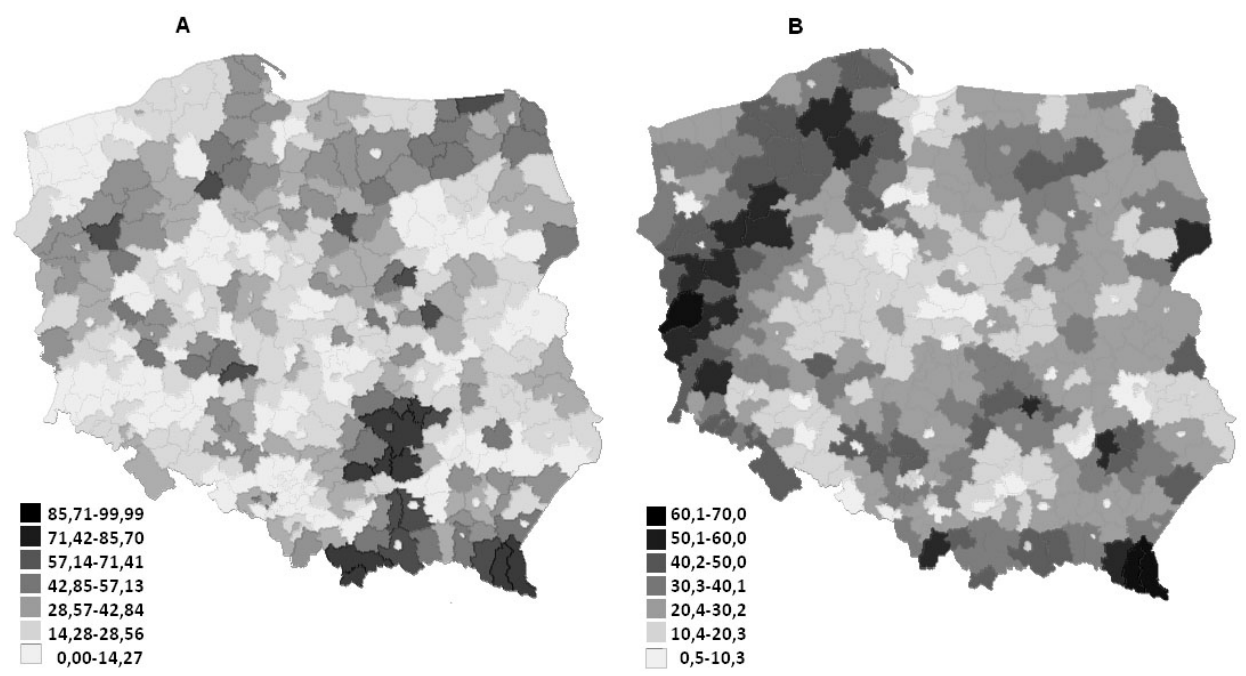

Ryc. 2. A - Udział obszarów prawnie chronionych w powierzchni ogółem oraz B - wskaźnik lesistości powiatów W 2014 r. (\%)

Źródło: GUS http://wskaznikizrp.stat.gov.pl (wygenerowano 5-8.04.2016).

A - Share of legally protected area in the total area and B-indicator of county forestation in 2014 (\%)

Source: CSO http://wskaznikizrp.stat.gov.pl (generated 5-8.04.2016).

\begin{tabular}{|c|c|r|r|r|r|r|r|}
\hline $\mathbf{2 0 0 7}$ & $\mathbf{2 0 0 8}$ & \multicolumn{1}{|c|}{$\mathbf{2 0 0 9}$} & \multicolumn{1}{c|}{$\mathbf{2 0 1 0}$} & \multicolumn{1}{c|}{$\mathbf{2 0 1 1}$} & \multicolumn{1}{c|}{$\mathbf{2 0 1 2}$} & \multicolumn{1}{c|}{$\mathbf{2 0 1 3}$} & $\mathbf{2 0 1 4}$ \\
\hline 28,9 & 29,0 & 29,1 & 29,2 & 29,2 & 29,3 & 29,4 & 29,4 \\
\hline 32,31 & 32,31 & 32,31 & 32,44 & 32,46 & 32,46 & 32,51 & 32,51 \\
\hline- & - & - & 1,38 & 2,13 & 1,96 & 2,65 & 6,58 \\
\hline 727,1 & 745,8 & 751,8 & 773 & 762,7 & 760,8 & 757,2 & 739,1 \\
\hline 743,6 & 764,6 & 764,9 & 785,4 & 773,7 & 768,6 & 761,4 & 735 \\
\hline 705,8 & 721,2 & 736,2 & 753,8 & 745,6 & 748,7 & 750,6 & 745,4 \\
\hline 223269,4 & 216319,0 & 203125,6 & 216155,4 & 220928,0 & 216513,7 & 217491,9 & 209067,3 \\
\hline 95,0 & 77,0 & 62,0 & 63,0 & 58,0 & 52,0 & 50,0 & 47,0 \\
\hline- & 1,1 & 1,4 & 1,2 & 0,8 & 0,7 & 0,9 & 0,8 \\
\hline- & 1260 & 2026 & 1595 & 806 & 801 & 703 & 533 \\
\hline
\end{tabular}


Zalesienie jest jednym z wyznaczników walorów naturalnych danego terenu, ale jego stopień podlega wpływom antropogenicznym, dlatego w ujęciu lokalnym poza wskaźnikiem lesistości istotnym dla oceny potencjału kreacji funkcji prośrodowiskowych danego obszaru może być wskaźnik intensywności zalesień. W badanym okresie proces zalesiania gruntów był jednakże pobudzany narzędziami wsparcia (PROW 2006) i jako taki może okazać się wadliwym miernikiem oddolnego potencjału kreowania funkcji prośrodowiskowych. Dla zobrazowania zależności intensywności zalesień od dostępu do form wsparcia na ryc. 3 przedstawiono dane z lat 2004 (początki wspierania zalesień), 2007 (okres dostępu do programów wspierających) oraz 2014 (wyczerpanie środków na zalesienia z poprzedniej - 2007-2013 - perspektywy budżetowej i oczekiwanie na uruchomienie środków z perspektywy 2014-2020).

Analizując informacje o stanie powietrza atmosferycznego i przeciwdziałaniu zmianom klimatu, można by domniemywać, że obszary o wysokim poziomie emisji zanieczyszczeń (gazowych bądź pyłowych) będą charakteryzować się również relatywnie większymi wydatkami z budżetów gmin na ochronę powietrza. Zestawienie kartogramów prezentujących wydatki gmin na ochronę powietrza atmosferycznego oraz rozkład terytorialny emisji zanieczyszczeń pyłowych i gazowych (2014) z zakładów szczególnie uciążliwych przedstawiono na ryc. 4 . Z porównania wizualnego wynika, że wysoki poziom wydatków na ochronę powietrza i klimatu nie dotyczył obszarów o wysokim poziomie emisji zanieczyszczeń, lecz powiatów Polski południowo-wschodniej - najwyższe wartości odnotowano w powiatach województwa lubelskiego, zajmującego czołowe miejsca w produkcji rolniczej systemem ekologicznym. Wskazuje to na dbałość lokalnych jednostek o zachowanie naturalnego bogactwa tych terenów, którego walory stanowią ważny składnik prowadzonej tam gospodarki.

Wskaźniki ładu środowiskowego odnoszące się do energetyki i gospodarki odpadami pośrednio obrazują postawy mieszkańców i są bliskie wskaźnikom ładu społecznego z dziedziny wzorców konsumpcji. Należy zaznaczyć, że dane dotyczące zużycia energii elektrycznej na jednego mieszkańca są jedynym wskaźnikiem ładu środowiskowego, który w analizowanej bazie GUS występuje w podziale na miasto i wieś. Na ryc. 5 zestawiono kartogramy przedstawiające wartości tego wskaźnika w 2004 i 2014 roku. Na początku badanego okresu w zachodniej części kraju było wyższe zużycie energii elektrycznej niż w regionach Polski wschodniej. W następnym dziesięcioleciu sytuacja uległa zrównoważeniu, aczkolwiek południowo-wschodnią część kraju nadal charakteryzowało niższe zużycie energii elektrycznej przypadające na jednego mieszkańca obszarów wiejskich.

Analiza tego wskaźnika bez odniesienia do poziomu intensywności produkcji ani informacji odnośnie udziału kosztów energii w budżecie gospodarstw domowych nie stanowi wymiernych podstaw do wnioskowania o prośrodowiskowych postawach mieszkańców danych obszarów. Dopiero powiązanie wielu zmiennych (w tym informacji o efektywności wykorzystania zasobu) mogłoby wskazywać, że wartość tego wskaźnika wynika np. ze świadomości ekologicznej danej społeczności, co przekładałoby się na miarę oddolnego czynnika stymulującego podjęcie działań korzystnych dla środowiska.

Interesującym na potrzeby analizy oddolnego potencjału funkcji prośrodowiskowych danego terytorium wydaje się wskaźnik informujący o liczbie i powierzchni dzikich wysypisk. Według badania świadomości i zachowań ekologicznych z 2014 r. (Badanie... 2014, s. 53) „dzikie wysypiska są problemem wsi i małych miast do 20 tysięcy mieszkańców”. Niestety pomimo dostępności na liście wskaźników GUS aplikacji dotyczącej wysypisk 
2004

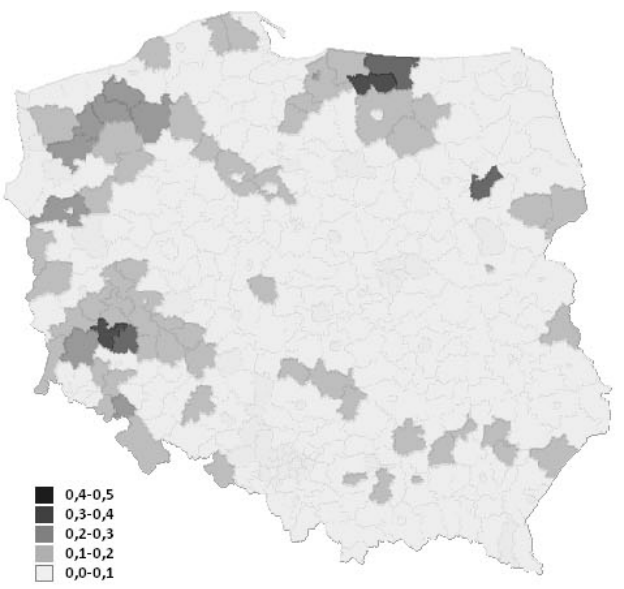

2007

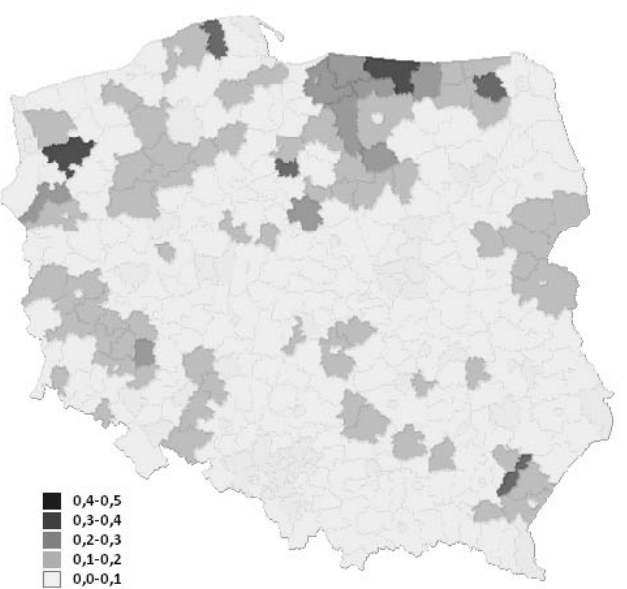

2014

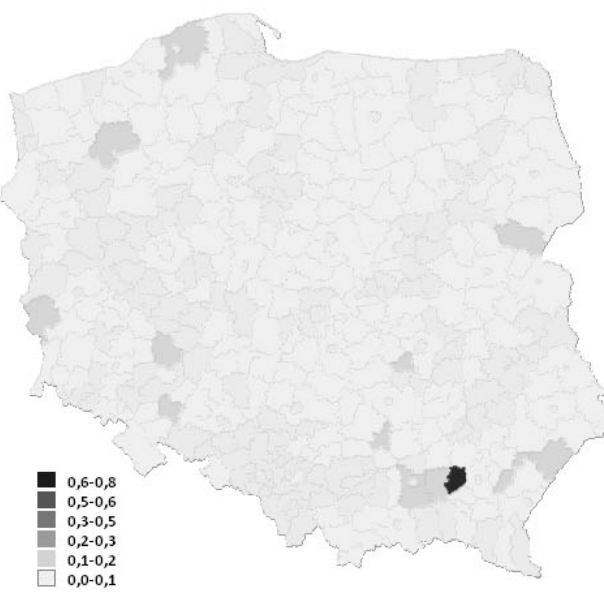

Ryc. 3. Dynamika intensywności zalesień wg powiatów latach 2004, 2007, 2014 (\%)

Źródło: GUS http://wskaznikizrp.stat.gov.pl (wygenerowano 05.2017).

Development of afforestation intensity in 2004, 2013, 2014 (\%)

Source: CSO http://wskaznikizrp.stat.gov.pl (generated 05.2017). 
A

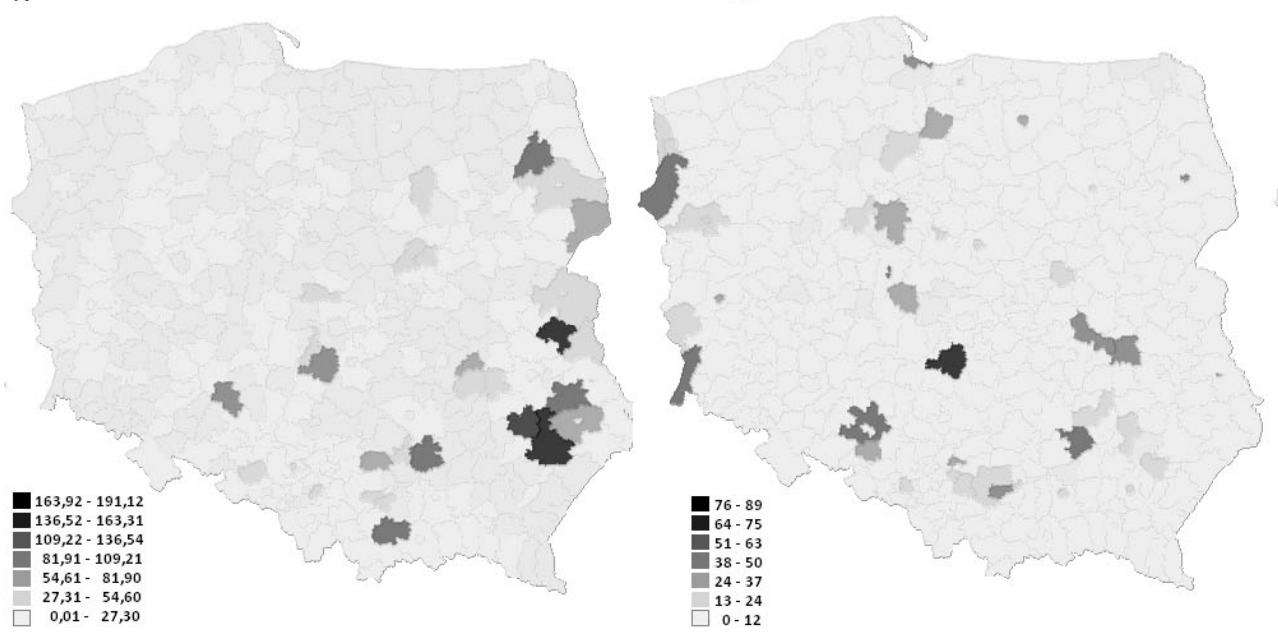

B2

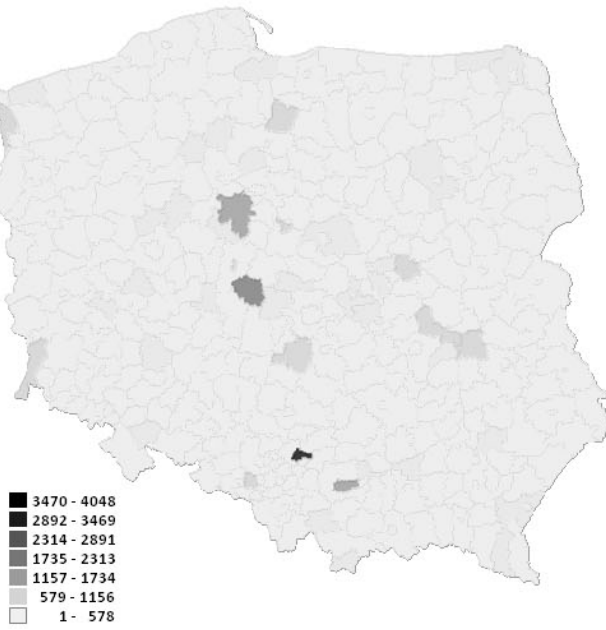

Ryc. 4. Ochrona powietrza i klimatu w 2014 r. wg powiatów. A - poziom wydatków gmin na ochronę powietrza atmosferycznego i klimatu (zł/1 mieszkańca); B - emisja zanieczyszczeń powietrza z zakładów szczególnie uciążliwych (kt/rok): B1- gazowe, B2 - pyłowe.

Źródło: GUS http://wskaznikizrp.stat.gov.pl (wygenerowano 5-8.04.2016).

Air and climate protection by counties. A - Commune expenditure on climate and air protection (PLN per capita), B - Emissions of carbon dioxide from plants especially noxious to air purity (kt/year); B1-Gases, B2 - Particulates.

Source: CSO http://wskaznikizrp.stat.gov.pl (generated 5-8.04.2016). 
w module krajowym, regionalnym i lokalnym, miernik ten wykazuje znaczne luki danych dla poszczególnych powiatów, co uniemożliwia porównywalność obszarów oraz wiarygodne wnioskowanie odnośnie potencjału kreowania funkcji prośrodowiskowych.
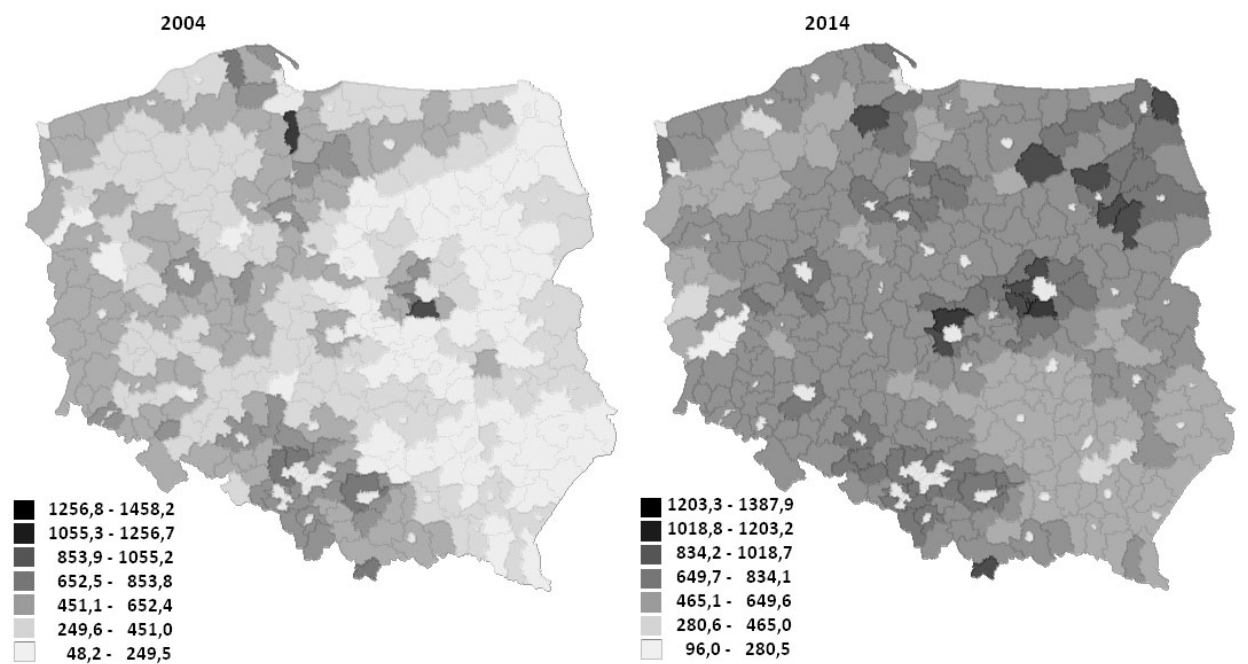

Ryc. 5. Zużycie energii elektrycznej w kWh na 1 mieszkańca na wsi

Źródło: GUS http://wskaznikizrp.stat.gov.pl (wygenerowano 5-8.04.2016).

Electricity consumption in $\mathrm{kWh}$ per capita in rural areas

Source: CSO http://wskaznikizrp.stat.gov.pl (generated 5-8.04.2016).
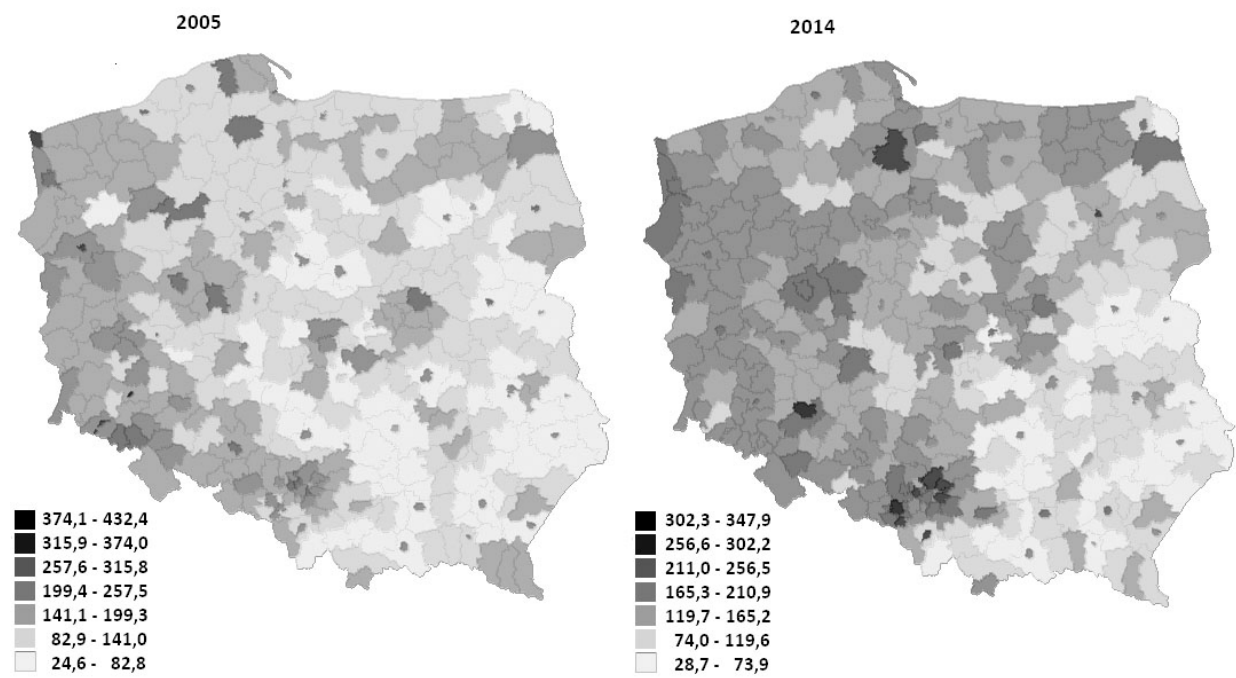

Ryc. 6. Ilość zmieszanych odpadów komunalnych z gospodarstw domowych zebranych w ciągu roku (kg/1 mieszkańca)

Źródło: GUS http://wskaznikizrp.stat.gov.pl (wygenerowano 5-8.04.2016).

Mixed municipal waste from households collected during the year (kg per capita)

Source: CSO http://wskaznikizrp.stat.gov.pl (generated 5-8.04.2016). 
Znacznie pełniej prezentuje się baza danych dotycząca ilości zmieszanych odpadów komunalnych zebranych z gospodarstw domowych. Jakkolwiek pomiędzy skrajnymi analizowanymi latami (2005 i 2014) nastąpiła w Polsce zmiana regulacji prawnych (Dz.U. 2013 poz. 21) odnośnie gospodarowania odpadami, wymuszająca zmianę postaw konsumpcyjnych, to wizualizacja danych pokazuje wyraźną różnicę pomiędzy zachodnią i wschodnią częścią kraju (ryc. 6). Brak danych i wskaźników o odpadach segregowanych i dzikich wysypiskach uniemożliwia jednoznaczne stwierdzenie o prośrodowiskowym potencjale wschodniej części kraju. Badania świadomości ekologicznej Polaków (Badanie... 2013) wskazywały, że w 2013 r. ok. 59\% (jeden z największych odsetków respondentów według miejsca zamieszkania) mieszkańców wsi regularnie segregowało odpady, zaś 69\% korzystało z zakupowych toreb wielokrotnego użytku (dla porównania w miastach powyżej 500 tys. mieszkańców segregacji dokonywało tylko ok. 31\% ich mieszkańców).

Podsumowując spostrzeżenia z wyżej przytoczonych wizualizacji wskaźników ładu środowiskowego (zachowując świadomość ich niedoskonałości), można bardzo ostrożnie domniemywać o przewadze potencjału prośrodowiskowego w południowo-wschodniej części kraju. Obszary te charakteryzuje nie tylko bogactwo naturalne (wysoki udział powierzchni zalesionych i prawnie chronionych), ale także niższe zużycie energii elektrycznej na osobę, mniejsza ilość wytwarzanych odpadów oraz lepszy stan powietrza. Potwierdzenie tej hipotezy wymagałoby jednakże pogłębionej analizy, w oparciu o znacznie dokładniejsze dane.

\section{Charakterystyka wybranych wskaźników ładu społecznego i gospodarczego}

O lokalnym potencjale wytwarzania funkcji prośrodowiskowych, poza czynnikami wprost dotyczącymi jakości środowiska naturalnego, może świadczyć również jakość kapitału społecznego, wynikająca z poziomu edukacji, a także z nabytych wzorców konsumpcji. W tabeli 2 zaprezentowano dynamikę wybranych wskaźników ładu społecznego w latach 2004-2014 na poziomie kraju, natomiast kolejne kartogramy prezentują poziom wybranych wskaźników wg powiatów.

Z analiz przeprowadzanych dla Ministerstwa Środowiska (Badanie... 2013) wynika zaskakujący wniosek, że wraz ze wzrostem poziomu wykształcenia spada świadomość problemów

Tabela 2. Dynamika wartości wskaźników ładu społecznego dla Polski w latach 2004-2014

\begin{tabular}{|c|c|c|c|c|}
\hline & Wyszczególnienie & 2004 & 2005 & 2006 \\
\hline \multicolumn{2}{|c|}{ Liczba samochodów osobowych na 1000 ludności } & 313,7 & 323,4 & 351,1 \\
\hline \multicolumn{2}{|c|}{ Przeciętna powierzchnia użytkowa mieszkania (m²/os.) } & 22,9 & 23,2 & 23,5 \\
\hline \multirow{3}{*}{$\begin{array}{l}\text { Zużycie mediów } \\
\text { w gospodarstwach } \\
\text { domowych w ciągu } \\
\text { roku na } 1 \text { mieszkańca }\end{array}$} & energii elektrycznej (kWh) & 597,3 & 696,1 & 723,2 \\
\hline & $\operatorname{gazu}\left(\mathrm{m}^{3}\right)$ & 99,0 & 101,0 & 104,0 \\
\hline & wody $\left(\mathrm{m}^{3}\right)$ & 32,2 & 32,0 & 32,0 \\
\hline \multirow{2}{*}{$\begin{array}{l}\text { Zdawalność egzami- } \\
\text { nów maturalnych (\%) }\end{array}$} & w szkołach ponadgimnazjalnych zawodowych & 86,1 & 81 & 78,5 \\
\hline & w liceach ogólnokształcących & - & - & - \\
\hline \multicolumn{2}{|c|}{$\begin{array}{l}\text { Udział dzieci objętych wychowaniem przedszkolnym w ogólnej liczbie } \\
\text { dzieci w wieku 3-5 lat na wsi (\%) }\end{array}$} & 17,5 & 19,1 & 21,4 \\
\hline
\end{tabular}

- brak danych.

Źródło: GUS http://wskaznikizrp.stat.gov.pl (wygenerowano 5-8.04.2016), dane dotyczące wychowania przed- 
związanych z ochroną środowiska, a zarazem rośnie przekonanie o uzależnieniu stanu środowiska od aktywności władz lokalnych. Zatem paradoksalnie o oddolnym potencjale postaw prośrodowiskowych świadczyłby niższy poziom wykształcenia. Jednakże ten sam raport wskazuje, że osoby z wyższym wykształceniem znacznie częściej segregują odpady, częściej podczas zakupów wybierają towary w opakowaniach ekologicznych oraz są przekonane o roli osobistych działań w przeciwdziałaniu zmianom klimatu. Osoby z wyższym wykształceniem również częściej deklarują wybór rozwiązań ekologicznych (np. minimalizujących zużycie energii czy wody) wiążący się z poniesieniem dodatkowych kosztów. Natomiast analizując wskaźniki ładu społecznego GUS odnośnie jakości kształcenia w ponadgimnazjalnych szkołach zawodowych (ryc. 7), można odnotować w badanym okresie spadek poziomu zdawalności egzaminów maturalnych oraz zmianę obszarów o wysokiej zdawalności egzaminów.
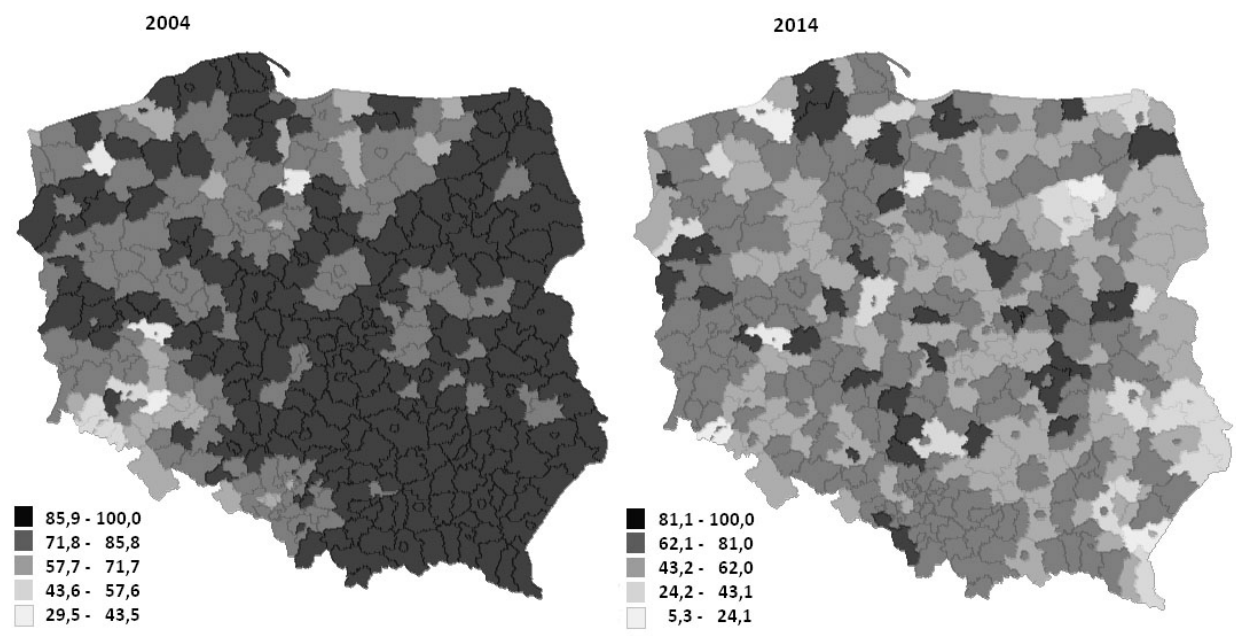

Ryc. 7. Wskaźnik jakości kształcenia i poziomu wiedzy uczniów - zdawalność egzaminów maturalnych (\%) w szkołach ponadgimnazjalnych zawodowych

Źródło: GUS http://wskaznikizrp.stat.gov.pl (wygenerowano 5-8.04.2016).

Ratios of the quality of education and the level of students' knowledge - the passing rate for the school leaving examination ('matura') in the vocational upper secondary schools

Source: CSO http://wskaznikizrp.stat.gov.pl (generated 5-8.04.2016).

\begin{tabular}{|c|c|c|c|c|c|c|c|}
\hline $\mathbf{2 0 0 7}$ & $\mathbf{2 0 0 8}$ & $\mathbf{2 0 0 9}$ & $\mathbf{2 0 1 0}$ & $\mathbf{2 0 1 1}$ & $\mathbf{2 0 1 2}$ & $\mathbf{2 0 1 3}$ & $\mathbf{2 0 1 4}$ \\
\hline 382,7 & 421,6 & 432,2 & 447,4 & 470,3 & 486,4 & 503,7 & 519,9 \\
\hline 23,8 & 24,2 & 24,6 & 25,3 & 25,6 & 25,9 & 26,3 & 26,7 \\
\hline 727,1 & 745,8 & 751,8 & 773,0 & 762,7 & 760,8 & 757,2 & 739,1 \\
\hline 99,9 & 99,5 & 101,5 & 110,0 & 100,1 & 103,4 & 105,7 & 96,7 \\
\hline 31,5 & 31,8 & 31,3 & 31,1 & 31,2 & 31,2 & 30,9 & 31,1 \\
\hline 81,6 & 76,7 & 77,7 & 73,3 & 72,6 & 74,6 & 77,4 & 68,6 \\
\hline- & 92,5 & 92,7 & 90,8 & 88,8 & 90 & 91,1 & 87,7 \\
\hline 23,1 & 28,5 & 37,5 & 41,0 & 49,3 & 50,8 & 55,7 & 60,8 \\
\hline
\end{tabular}

szkolnego (wygenerowano 05.2017) 
Zdawalność egzaminów maturalnych stanowi pośredni wskaźnik potencjalnej gotowości do kontynuacji nauki na studiach wyższych. Jednakże nie odzwierciedla on stanu wiedzy przyrodniczej absolwentów szkół ponadgimnazjalnych, dlatego informacje pozyskane z bazy wskaźników zrównoważonego rozwoju GUS na użytek pełniejszej oceny warto byłoby uzupełnić o informacje z zewnętrznych baz danych, np. Okręgowej Komisji Egzaminacyjnej (wyniki egzaminów gimnazjalnych z przyrody).

Istotną rolę w nabywaniu wzorców konsumpcyjnych we wczesnym okresie życia ma rodzina i grupa rówieśnicza. Wczesna edukacja - w tym wychowanie przedszkolne, stanowi jedną z możliwości kształtowania świadomości ekologicznej dzieci i ich rodzin. W latach 2004-2014 nastąpiła znacząca poprawa dostępu dzieci wiejskich do edukacji przedszkolnej w całym kraju. Najwyższy poziom tego wskaźnika charakteryzuje powiaty stanowiące obszary funkcjonalne aglomeracji miejskich. Niestety zmienna ta (podobnie jak wskaźnik kształcenia i poziomu wiedzy uczniów) nie wnosi informacji o poziomie wiedzy przyrodniczej przedszkolaków.
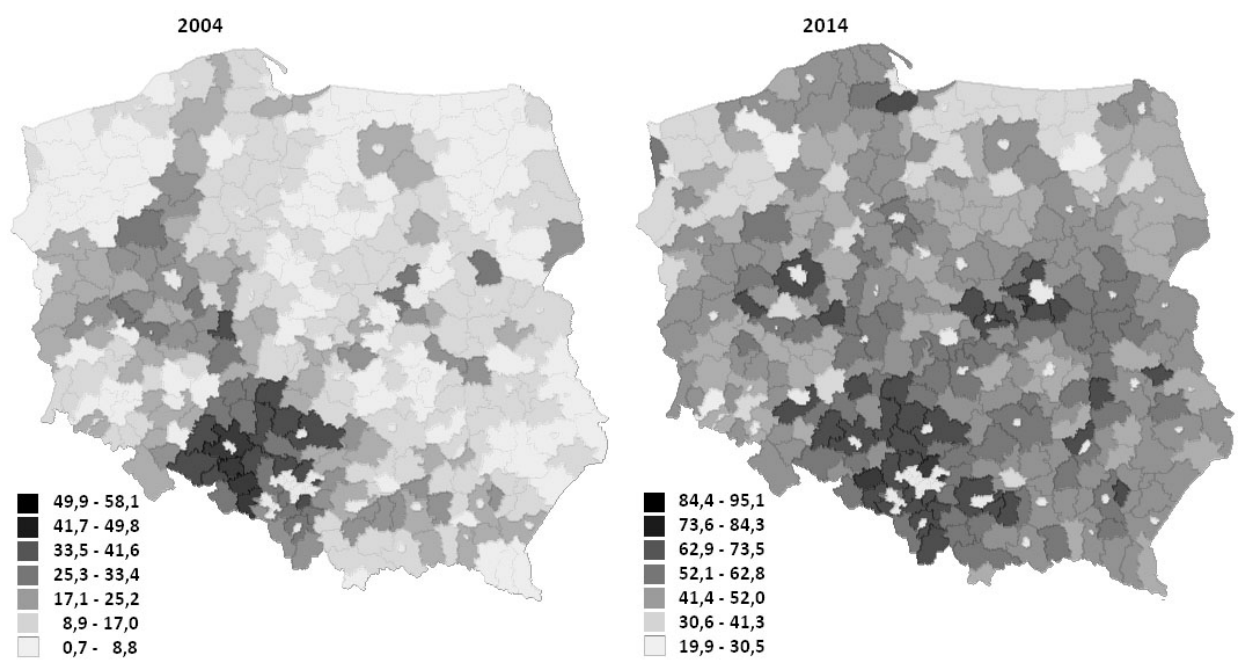

Ryc. 8. Udział dzieci objętych wychowaniem przedszkolnym w ogólnej liczbie dzieci w wieku 3-5 lat na wsi (\%) Źródło: GUS http://wskaznikizrp.stat.gov.pl (wygenerowano 05.2017).

Children covered by pre-school education in percentage of the total number of children aged 3-5 in rural areas (\%)

Source: CSO http://wskaznikizrp.stat.gov.pl (generated 05.2017).

Wzorce konsumpcji na poziomie lokalnym (w aplikacji GUS) charakteryzują wskaźniki opisujące zużycie mediów w gospodarstwach domowych oraz liczbę samochodów przypadającą na mieszkańców. Zauważa się, iż południowo-wschodnia część kraju charakteryzuje się niższym zużyciem mediów. Dane o zużyciu energii elektrycznej w gospodarstwach domowych są zbieżne ze wskaźnikiem ładu środowiskowego, omówionym powyżej dla mieszkańców wsi (porównaj ryc. 5). 
2004

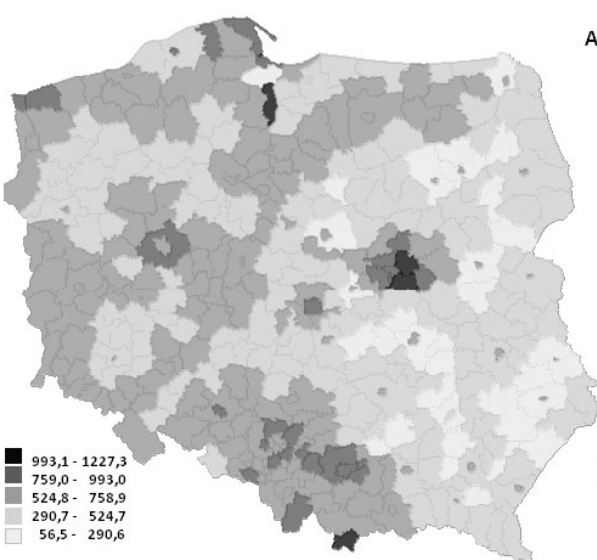

2004

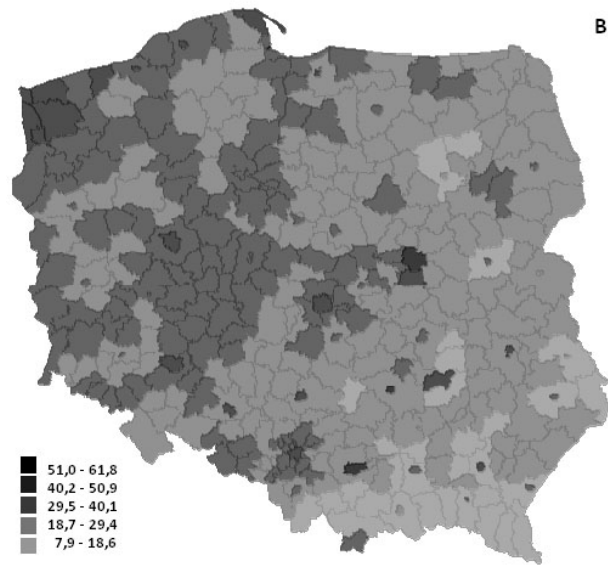

2014

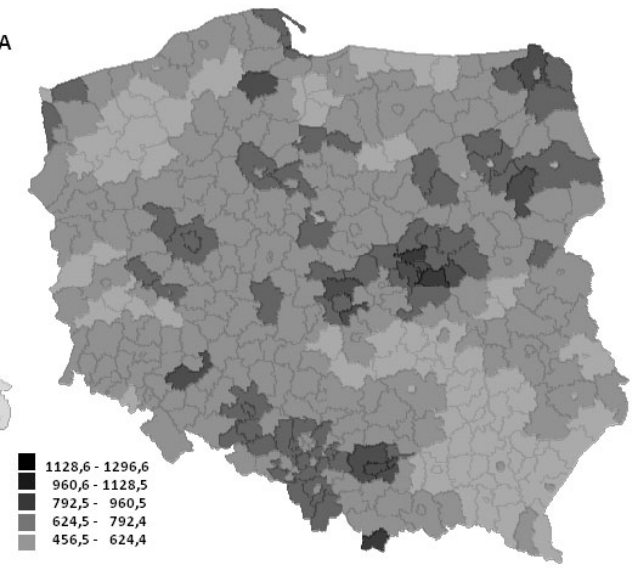

2014

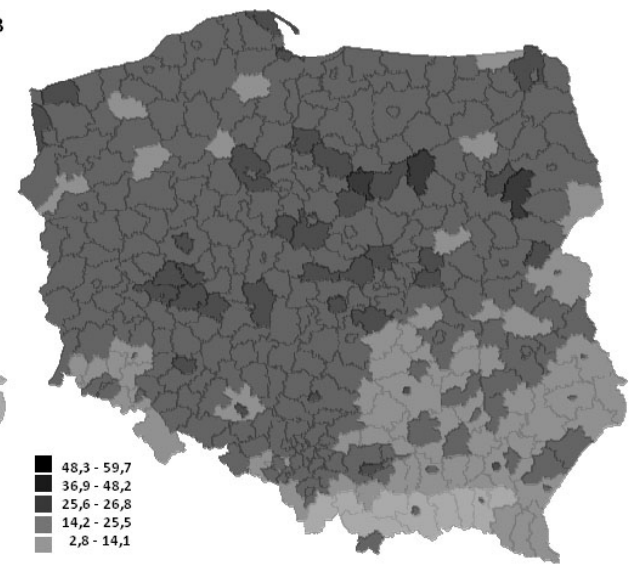

Ryc. 9. Zużycie mediów w gospodarstwach domowych w ciągu roku na jednego mieszkańca: A - energii elektrycznej (kWh), B - wody $\left(\mathrm{m}^{3}\right)$

Źródło: GUS http://wskaznikizrp.stat.gov.pl (wygenerowano 5-8.04.2016).

Utilities consumption in households during the year per capita: A-energy consumption (kWh), B-water $\left(\mathrm{m}^{3}\right)$ Source: CSO http://wskaznikizrp.stat.gov.pl (generated 5-8.04.2016).

Należy pamiętać, że terytorialne różnice w zużyciu mediów poza odmiennością wzorców konsumpcji mogą wynikać także z wymienionych już przyczyn dochodowych czy z dostępności do infrastruktury (np. do wodociągu), a także z historycznych uwarunkowań rozwoju systemu osadniczego.

Pośród wskaźników ładu społecznego z dziedziny charakteryzującej ubóstwo i warunki życia do analizy wybrano powierzchnię użytkową mieszkania przypadająca na 1 osobę (ryc. 10). Wskaźnik ten pośrednio powiązany jest z poziomem zużycia mediów i zależy od podobnych (wyżej wymienionych) uwarunkowań. Jego obecność w analizie potencjału kreacji funkcji prośrodowiskowych jest o tyle istotna, że jego wartość w pewnej mierze może obrazować lokalne tendencje suburbanizacyjne. Niekontrolowany przyrost 
zabudowy mieszkalnej niejednokrotnie skutkuje stopniowym zanikiem wiejskiego charakteru danego obszaru (Sawicka i Fogel 2016; Majewska 2012; Legutko-Kobus 2014), a presja związana z pełnieniem funkcji mieszkalnych prowadzi do osłabienia funkcji prośrodowiskowych. Południowo-wschodnia Polska oraz pas pojezierzy charakteryzowały się w badanych latach najniższymi wartościami tego wskaźnika (podobnym zasięgiem charakteryzowały się powiaty o najwyższym udziale obszarów objętych prawną ochroną przyrody - ryc. 2a)
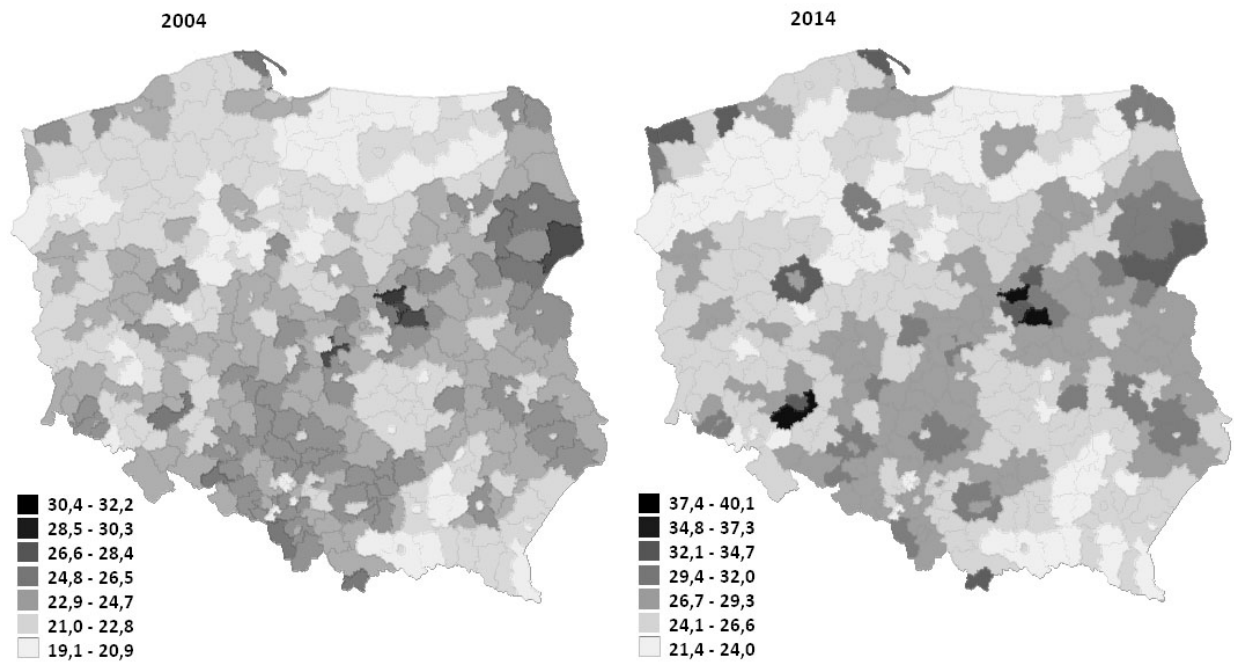

Ryc. 10. Przeciętna powierzchnia użytkowa mieszkania na 1 osobę $\left(\mathrm{m}^{2}\right)$ Źródło: GUS http://wskaznikizrp.stat.gov.pl (wygenerowano 5-8.04.2016). Average floor area of dwelling per capita $\left(\mathrm{m}^{2}\right)$

Source: CSO http://wskaznikizrp.stat.gov.pl (generated 5-8.04.2016).

Dane o liczbie aut przypadających na tysiąc osób, w bazie wskaźników zrównoważonego rozwoju GUS na poziomie powiatów, dostępne są jedynie dla ostatnich 5 analizowanych lat. Ich przestrzenny obraz (ryc. 11) wskazuje na zmniejszenie dysproporcji pomiędzy poszczególnymi powiatami oraz na wzrost ogólnej liczby użytkowanych samochodów.

Wskaźnik ładu społecznego charakteryzujący liczbę samochodów wiąże się ze wskaźnikami ładu gospodarczego z dziedziny transportu. W module lokalnym aplikacji GUS dostępne są wskaźniki dotyczące udziału wydatków na drogi publiczne w wydatkach ogółem gmin i powiatów, a także długość dróg lokalnych na 100 km² (wg rodzaju nawierzchni twardej i gruntowej) oraz długość ścieżek rowerowych (w odniesieniu do powierzchni, jak i liczby mieszkańców). Analizując lokalny potencjał pełnienia funkcji prośrodowiskowych przyjęto, że jednym z jego mierników może być wskaźnik odnoszący się do ścieżek rowerowych. Dostępne dane dotyczące tego wskaźnika obejmują lata 2011-2014. Największą długością ścieżek w przeliczeniu na powierzchnię charakteryzują się miasta wojewódzkie, dlatego też analizując potencjał kreowania funkcji prośrodowiskowych na obszarach Wiejskich, zdecydowano o wyborze wizualizacji wskaźnika ścieżek rowerowych w relacji do liczby mieszkańców (ryc. 12). 


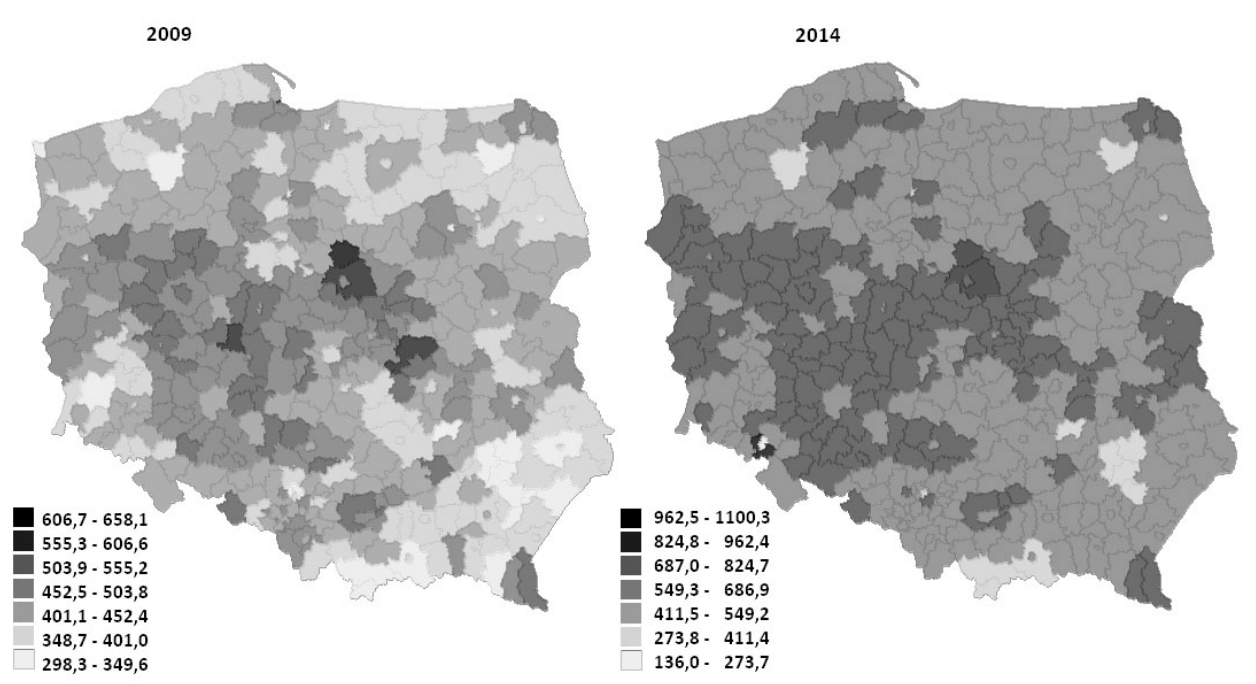

Ryc. 11. Liczba samochodów osobowych na 1000 ludności

Źródło: GUS http://wskaznikizrp.stat.gov.pl (wygenerowano 5-8.04.2016).

Number of passenger cars per 1,000 population

Source: CSO http://wskaznikizrp.stat.gov.pl (generated 5-8.04.2016).
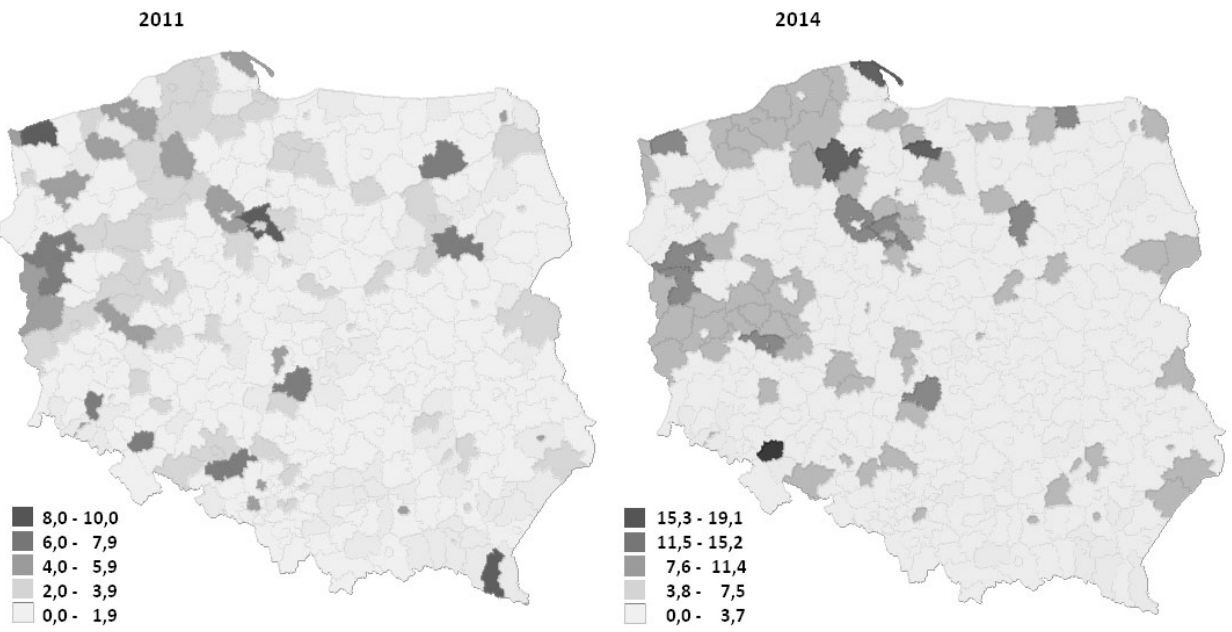

Ryc. 12. Ład gospodarczy - długość ścieżek rowerowych wg powiatów (km na 10 tys. mieszkańców) Źródło: GUS http://wskaznikizrp.stat.gov.pl (wygenerowano 5-8.04.2016).

Economic domain - Length of bicycle lanes per county ( $\mathrm{km}$ per 10 thous. population) Source: CSO http://wskaznikizrp.stat.gov.pl (generated 5-8.04.2016).

Analiza powyższych wskaźników ładu społecznego i gospodarczego nasuwa spostrzeżenia podobne do podsumowania wskaźników ładu środowiskowego. Południowo-wschodnie obszary kraju cechuje niższa konsumpcja mediów w gospodarstwach domowych, korzystanie z mniejszej powierzchni mieszkalnej oraz niższy poziom zmotoryzowania mieszkańców. Otwarte pozostaje jednak pytanie, na ile zwizualizowane wzorce konsumpcji odzwierciedlają świadomość ekologiczną i postawy mieszkańców wobec 
wykorzystania zasobów naturalnych, a na ile podyktowane są zaszłościami historycznymi. Należy w tym miejscu zauważyć, że powstawanie ścieżek rowerowych odnotowują wybrane powiaty w północno-zachodniej części kraju. Obszary te odnotowują relatywnie wysokie (choć nie najwyższe w kraju) poziomy wskaźników dotyczących udziału dzieci wiejskich w wychowaniu przedszkolnym (porównaj 2004 r.) i zdawalności egzaminów maturalnych. Ewentualna przyszła zmiana wzorców konsumpcji badanych obszarów może skutkować zmniejszeniem prośrodowiskowego potencjału południowo-wschodniej Polski (wyrównywanie standardów życia w obrębie kraju) oraz jego przyrostem w części północno-zachodniej (edukacja i kształtowanie świadomości ekologicznej).

\section{Charakterystyka wybranych wskaźników ładu instytucjonalno-politycznego}

Jednostki samorządu terytorialnego mogą pozyskiwać środki na działania w zakresie ochrony środowiska między innymi z opłat eksploatacyjnych uiszczanych przez przedsiębiorstwa za prawo eksploatacji naturalnych zasobów mineralnych (tj. kruszce, surowce skalne, wody termalne, surowce energetyczne itp.). Ze względu na rzadkość ich występowania opłaty stanowią wpływy tylko w nielicznych jednostkach samorządu terytorialnego. Poziom opłat eksploatacyjnych przypadających na jednego mieszkańca w całym kraju w 2005 r. wynosił średnio 5,2 zł i wzrastał w kolejnych latach do 7,6 zł w 2014 r. Najwyższe wpływy w 2004 r. odnotowano w powiecie polkowickim - 445,2 zł i bełchatowskim 263,9 zł - w pozostałych wartość nie przekroczyła 130 zł. W 2014 r. wpływy w tych powiatach wynosiły odpowiednio 566,4 zł oraz 304 zł, zaś w sąsiadującym z powiatem bełchatowskim powiecie pajęczańskim 259,6 zł. W pozostałych powiatach wartość wpływów z tytułu opłat eksploatacyjnych na jednego mieszkańca nie przekroczyła 170 zł. Niskie zróżnicowanie przestrzenne tego wskaźnika poza wyżej wymienionymi powiatami decyduje o jego niskiej informacyjności w procesie oceny lokalnego potencjału kreacji funkcji prośrodowiskowych.

Pośród wskaźników ładu instytucjonalno-politycznego charakteryzujących dziedziny "otwartości i uczestnictwa" dane dostępne na poziomie powiatów dotyczyły frekwencji w wyborach samorządowych, udziału kobiet i osób z wyższym wykształceniem w lokalnych organach ustawodawczych, a także liczby organizacji pozarządowych w przeliczeniu na liczbę mieszkańców.

Pomiędzy rokiem 2005 i 2014 zaobserwowano w Polsce wzrost (z 21 do 33) liczby stowarzyszeń, fundacji i organizacji społecznych przypadających na 10 tys. mieszkańców. W 2014 r. najwięcej zarejestrowanych organizacji w przeliczeniu na mieszkańców posiadały miasta na prawach powiatu: Sopot (96/10 tys.) i Warszawa (71/10 tys.). W pozostałych liczba zarejestrowanych organizacji nie przekraczała 60. Na ryc. 13 przedstawiono wizualizację danych o liczbie organizacji pozarządowych w powiatach w latach 2005 i 2014 (bez Sopotu i Warszawy). 

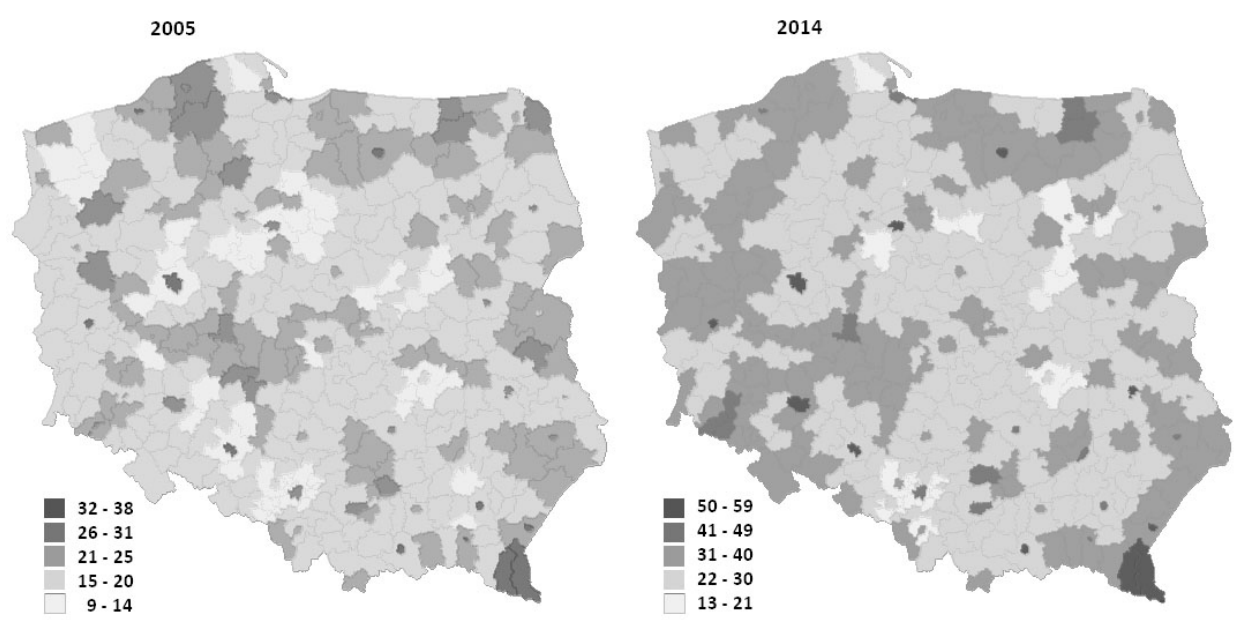

Ryc. 13. Liczba zarejestrowanych fundacji, stowarzyszeń i organizacji społecznych na 10 tys. mieszkańców powiatów (z pominięciem Sopotu i Warszawy)

Źródło: GUS http://wskaznikizrp.stat.gov.pl (wygenerowano 5-8.04.2016).

Number of foundations, associations and social organizations per 10 thous. population (excluding Sopot and Warsaw)

Source: CSO http://wskaznikizrp.stat.gov.pl (generated 5-8.04.2016).

Wskaźniki dotyczące udziału w wyborach oraz liczba organizacji pozarządowych świadczą o zaangażowaniu i włączeniu społecznym mieszkańców danego obszaru, a tym samym mogą informować o potencjale podejmowania inicjatyw lokalnych - w tym działań prośrodowiskowych. Podczas wyborów samorządowych w 2010 r. w powiatach Polski wschodniej była wyższa frekwencja wyborcza niż w Polsce zachodniej. W organach samorządowych w 2014 r. zasiadało więcej kobiet i osób z wyższym wykształceniem niż w roku 2005, jednakże nadal we wschodniej części kraju ich udział był niższy niż w powiatach zachodniej Polski.

Przywołane wskaźniki ładu instytucjonalno-politycznego wskazują na rosnący lokalny potencjał zachodniej części kraju. Odniesienie ich do przestrzennego obrazu wskaźników ładów społecznego i gospodarczego pozwala zauważyć, że w powiatach charakteryzujących się wzrostem liczby organizacji pozarządowych i relatywnie wyższym wykształceniem radnych odnotowywano także zwiększony udział dzieci wiejskich w edukacji przedszkolnej oraz przyrost długości ścieżek rowerowych. Organizacje pozarządowe rejestrowane były również we wschodnich powiatach województw lubelskiego i podkarpackiego charakteryzujących się wysokimi walorami naturalnymi (opisanymi wskaźnikami ładu środowiskowego). 

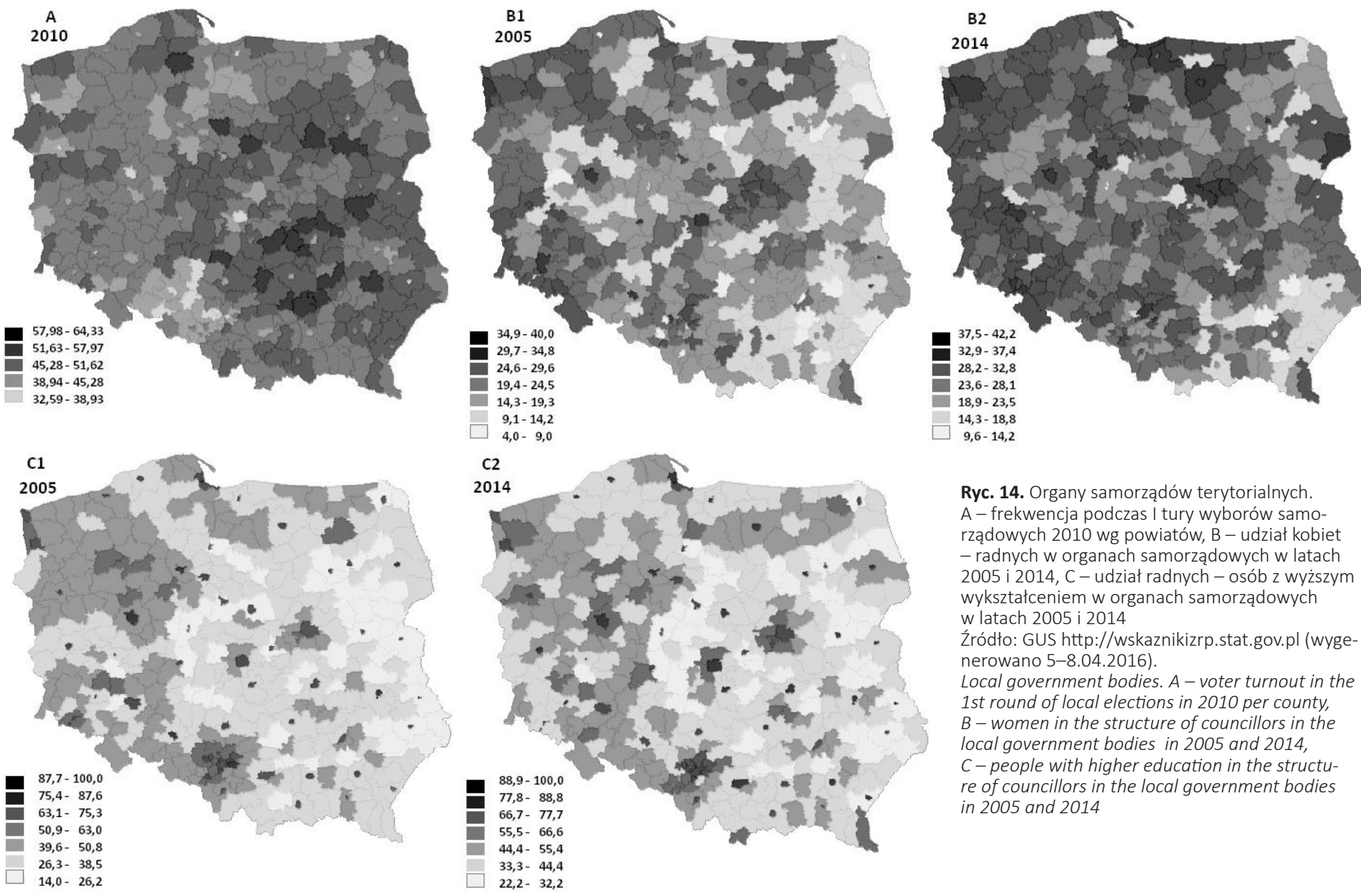

Ryc. 14. Organy samorządów terytorialnych. A - frekwencja podczas I tury wyborów samorządowych 2010 wg powiatów, B - udział kobiet - radnych w organach samorządowych w latach 2005 i 2014, C - udział radnych - osób z wyższym wykształceniem w organach samorządowych w latach 2005 i 2014

Źródło: GUS http://wskaznikizrp.stat.gov.pl (wygenerowano 5-8.04.2016)

Local government bodies. A-voter turnout in the 1st round of local elections in 2010 per county, $B$-women in the structure of councillors in the local government bodies in 2005 and 2014,

$\mathrm{C}$ - people with higher education in the structure of councillors in the local government bodies in 2005 and 2014 


\section{Podsumowanie}

Ukierunkowanie przyrodnicze funkcji obszarów wiejskich staje się znakiem XXI w. Zrozumienie procesu kreowania prośrodowiskowych funkcji w kontekście o wiele szerszym niż tylko finansowanie w ramach polityki rolnej pozwoli na analizę trwałości funkcji prośrodowiskowych w długim okresie.

Baza danych GUS dotycząca Wskaźników Zrównoważonego Rozwoju umożliwia wizualizację podstawowych informacji na poziomie powiatów, co pozwala scharakteryzować lokalny potencjał rozwojowy. Wybrane wskaźniki mogą stanowić przydatne narządzie badania obszarów pod kątem ich predyspozycji do świadczenia funkcji prośrodowiskowych. Ułomnością analizowanej bazy jest brak wyodrębnienia danych w podziale na obszary miejskie i wiejskie - niemniej jednak zwizualizowane dostępne dane pozwalają na wstępną ocenę potencjału danego terytorium. Analiza pozyskanych kartogramów pozwala na wyodrębnienie dwóch głównych obszarów interesujących pod względem lokalnego potencjału kreacji prośrodowiskowych funkcji obszarów wiejskich, tj. południowo-wschodniej Polski i pasa powiatów w części północno-zachodniej.

Na wysoki potencjał południowo-wschodniej Polski wskazują głównie wskaźniki ładu środowiskowego (odnoszące się do zasobów naturalnych, stanu powietrza czy gospodarki energią i odpadami), a także wskaźniki ładu społecznego dotyczące wzorców konsumpcji i warunków życia. Wartości wskaźników na tym obszarze w znacznej mierze wynikać mogą z uwarunkowań historycznych.

Drugim interesującym obszarem są wybrane powiaty pasa północno-zachodniego, w których kapitał ludzki oraz otoczenie administracyjne mogą odegrać istotną rolę w kreacji nowych funkcji prośrodowiskowych. Narzędzia edukacyjne, działalność organizacji pozarządowych oraz nastawienie lokalnych organów władzy mogą wpływać na poziom świadomości ekologicznej mieszkańców oraz podejmowanie przez nich inicjatyw służących środowisku naturalnemu.

Pomimo że wizualizacja danych bazy GUS modułu lokalnego pozwala jedynie na wstępną ocenę lokalnego potencjału powiatów, stanowi ważny etap prac nad jego badaniem. Pełne wnioskowanie o lokalnym potencjale do podejmowania działań prośrodowiskowych na obszarach wiejskich wymagałoby pogłębionych analiz danych z zastosowaniem narzędzi analizy statystycznej oraz wyważonego doboru zmiennych (w tym ograniczenia liczby wskaźników oraz ich odpowiedniej agregacji przestrzennej). Przeprowadzona analiza pozwoliła stwierdzić ograniczoną (pod kątem badania potencjału prośrodowiskowego) wartość informacyjną wybranych zmiennych z modułu lokalnego (np. wskaźnika wpływów z opłat eksploatacyjnych czy zdawalności egzaminów maturalnych). Jednocześnie pełniejszą ocenę potencjału lokalnego uniemożliwia ograniczona w porównaniu z modułem krajowym liczba wskaźników występujących w module lokalnym (np. brak informacji odnośnie energii ze źródeł odnawialnych). Na potrzeby przyszłych badań oznacza to konieczność eliminacji części zmiennych lub ich uzupełnienie bądź zastąpienie wskaźnikami pochodzącymi z zewnętrznych źródeł danych (np. OKE i BDL) w agregacji umożliwiającej wyodrębnienie obszarów wiejskich. 


\section{Literatura}

Adamowicz M., 2004, Wielofunkcyjne gospodarstwa rolne jako podmiot w rozwoju wsi i rolnictwa, [w:] M. Adamowicz (red.), Wiejskie gospodarstwa domowe w obliczu problemów transformacji, integracji i globalizacji, Prace Naukowe KPAiM, 33, Wydawnictwo SGGW, Warszawa, s. 25-42.

Brodzińska K., 2009, Perspektywy rozwoju rolnictwa w kontekście standardów w ochronie środowiska, Zeszyty Naukowe Szkoły Głównej Gospodarstwa Wiejskiego, Problemy Rolnictwa Światowego, 8 (XXIII), Wydawnictwo SGGW, s. 24-32.

Czyżewski A., Smędzik-Ambroży K., 2013, Intensywne rolnictwo w procesach specjalizacji i dywersyfikacji produkcji rolnej. Ujęcie regionalne i lokalne, Wydawnictwo PWN, Warszawa.

Dz.U. 2013 poz. 21, Ustawa z dnia 14 grudnia 2012 r. o odpadach.

Fałkowski J., 2010, Wielofunkcyjność rolnictwa jako przedmiot analizy ekonomicznej, [w] J. Wilkin (red), Wielofunkcyjność rolnictwa. Kierunki badań, podstawy metodologiczne i implikacje praktyczne, IRWiR PAN, Warszawa, s. 53-71.

GUS, 2015, Wskaźniki zrównoważonego rozwoju Polski, Katowice.

Huylenbroeck G., Vandermeulen V., Meetepenningen E., Verspecht A., 2007, Multifunctionality of Agriculture: A Review of Definitions, Evidence and Instruments, Living Rev. Landscape Res., 1 (3), artykuł online.

Klepacka-Kołodziejska D., 2008, Dopłaty kompensacyjne do obszarów o niekorzystnych warunkach gospodarowania jako element kształtujący rozwój społeczno-ekonomiczny obszarów Wiejskich, [w:] M. Drygas, A. Rosner (red.), Polska wieś i rolnictwo w Unii Europejskiej. Dylematy i kierunki przemian, Problemy wsi i rolnictwa, IRWiR PAN, s. 167-170.

Legutko-Kobus P., 2014, Kierunki rozwoju obszarów wiejskich w woj. Mazowieckim a implementacja rozwoju zrównoważonego, Biuletyn Komitetu Przestrzennego Zagospodarowania Kraju, 254, PAN, Warszawa.

Majewska A., 2012, Suburbanizacja w strefie metropolitalnej Warszawy, jako zagrożenia zrównoważonego rozwoju, [w:] A. Maciejewska (red.), Gospodarka przestrzenna w świetle wymagań strategii zrównoważonego rozwoju, Studia KPZK PAN, t. CXLII, Warszawa, s. 308-320.

PROW 2007-2013, 2006, Ministerstwo Rolnictwa i Rozwoju Wsi, Warszawa.

Miś T., 2013, Oddziaływanie instytucji na podejmowanie i realizację działań prośrodowiskowych na obszarach wiejskich, Roczniki Ekonomiczne Kujawsko-Pomorskiej Szkoły Wyższej w Bydgoszczy, 6, s. 297-321.

Niedzielski E., 2015, Funkcje obszarów wiejskich i ich rozwój, Zagadnienia Ekonomiki Rolnej, 2, Warszawa, s. 84-92.

Nowak A. Wójcik E., 2013, Poziom realizacji funkcji prośrodowiskowych w rolnictwie w województwie lubelskim, Zeszyty Naukowe SGGW, Ekonomika i Organizacja Gospodarki Żywnościowej, 101, Warszawa, s. 107-118.

Paszkowski S., 2001, Zrównoważony rozwój rolnictwa i obszarów wiejskich [w:] M. Kłodziński (red.), Gospodarka, człowiek, środowisko na obszarach wiejskich, IRWIR PAN, WFOSiGW woj. zachodniopomorskiego, AR w Szczecinie, Warszawa, s. 201-218.

Badanie świadomości i zachowań ekologicznych mieszkańców Polski, 2013, Raport BPS przygotowany dla Ministerstwa Środowiska, Sopot.

Sawicka Z., Fogel P., 2016, Zmiany funkcjonalne a przekształcenia ziemi rolnej na cele pozarolnicze na obszarach rozdrobnionych agrarnie, Wieś i Rolnictwo, 1 (170), s. 165-184.

Badanie świadomości i zachowań ekologicznych mieszkańców Polski, Badanie trackingowe - pomiar: październik 2014, TNS, 2014, Raport dla Ministerstwa Środowiska. 
Wilkin J., 2010, Wielofunkcyjność rolnictwa. Kierunki badań, podstawy metodologiczne i implikacje praktyczne, IRWiR PAN, Warszawa, s. 25-29.

Woś A., Zegar J., 2002, Rolnictwo społecznie zrównoważone, IERiGŻ, Warszawa.

Zegar J., 2012, Współczesne wyzwania rolnictwa, PWN, Warszawa.

\section{Summary}

The study attempts to evaluate the local factors which create pro-environmental functions (independent of external support) of rural areas. The assessment was based on statistical data (2004-2014) published by the Central Statistical Office of Poland. The national sustainable development indicators at the level of counties were analyzed, including indicators of environmental domain and selected indicators of domain such as: social, economic, institutional and political. The graphical presentation of the data enabled the spatial location of Polish counties on a map which may have a higher potential in the creation of pro-environmental functions. Choropleth maps included in the study are based on the visualization tool available in the Central Statistical Office's Application - Indicators for Sustainable Development - local module. 
http://rcin.org.pl 